\title{
Parental Child Abduction and the State: Identity, Diplomacy and the Duty of Care
}

\author{
Kristin Haugevik \\ Norwegian Institute of International Affairs (NUPI), N-0033 Oslo, Norway \\ kmh@nupi.no
}

\section{Summary}

States alternate between the roles of 'caretaker' and 'rescuer' when providing care to citizens abroad. This article suggests that they are more likely to assume the 'rescuer' role when core values underpinning their self-identity are at stake. This dynamic is explored by examining a case where a Norwegian mother re-abducted her two children from Morocco. In the process, Norway's foreign minister authorized shielding the children at the Norwegian Embassy in Rabat, citing 'Norway's duty to protect two Norwegian minors in fear of their lives'. A diplomatic conflict between Norway and Morocco followed. The Norwegian response must be seen in light of Norway's selfidentity as a frontrunner for children's rights. Ultimately, helping the children 'had' to trump concerns about diplomatic costs. The broader dilemmas that this case exemplifies should be relevant also to other cases where a state's concern for a child citizen is pitted against its obligation to diplomatic conventions.

\section{Keywords}

duty of care - diplomacy - parental child abduction - identity - ministry of foreign affairs - Norway

* The research behind this article was funded by the Research Council of Norway through the project 'Duty of Care: Protection of Citizens Abroad' (238066/H2o). Early versions of the manuscript were presented at workshops in Oslo, Atlanta and The Hague in 2016. The author would like to thank Rebecca Adler-Nissen, Morten S. Andersen, Benjamin de Carvalho, Amanda Cellini, Nina Græger, Xavier Guillaume, Minda Holm, Marcus Holmes, Jorg Kustermans, Anna Leander, Halvard Leira, Jan Melissen, Iver Neumann, Cian O’Driscoll, Maaike Okano-Heijmans and Pål Røren for their comments. Special thanks to The Hague Journal of Diplomacy's editorial team and the anonymous peer reviewers for their constructive feedback and suggestions.

(C) KRISTIN HAUGEVIK, 2017 | DOI 10.1163/1871191X-11302010

This is an open access article distributed under the terms of the prevailing CC-BY license at the time of publication. 


\section{Introduction}

Modern welfare states spend a considerable amount of time and resources providing care to their citizens, also when citizens are travelling or residing overseas. Foreign ministries are increasingly expected 'to assist citizens any-

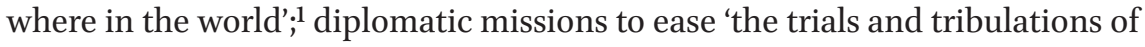
their destitute, drunken and imprisoned compatriots'.2 Against this backdrop, modern welfare states' 'duty of care' for their citizens abroad could perhaps be seen as an extension of the social contract between state and subjects - a state's responsibility for its citizens' safety and well-being does not stop at the border. $^{3}$ On the other hand, international law places clear limitations on the degree to which states can provide care to their citizens on foreign territory. While the Vienna Convention on Consular Relations (1963) identifies 'helping and assisting nationals' as a chief consular task, it also makes it clear that such assistance always must be in agreement with 'the laws and regulations of the receiving States. ${ }^{4}$ Thus, and as a general rule, one state's sovereign rights curb another's ability to help citizens in trouble abroad.

Why do states sometimes challenge this established order, and provide care to distressed citizens overseas beyond what diplomatic conventions prescribe? What are their own given explanations, and what may be the political and diplomatic costs of putting citizen care before diplomatic conventions? As part of this special issue's collective enquiry into states' duty of care for nationals abroad, this article sets out from the presumption that states alternate between two roles — that of 'caretaker' and that of 'rescuer' — when providing care to citizens travelling or residing abroad. On official webpages and in information pamphlets, states routinely portray themselves as 'caretakers'. They inform thoroughly about the kinds of assistance they can offer to nationals in need of help on foreign territory, but they are also careful to inform about the limitations of what they can do. In brief, embassies are neither travel agents nor insurance companies, and they are committed to respecting local jurisdictions in the host state. Accordingly, what a state can offer its citizens will in many cases be limited to 'help to self-help' — practical advice and support.

1 See Maaike Okano-Heijmans, 'Consular Assistance and Consular Diplomacy', in Jan Melissen and Ana Mar Fernandez (eds), Consular Affairs and Diplomacy (Leiden: Brill, 2011), p. 23.

2 Richard Langhorne and Keith Hamilton, The Practice of Diplomacy: Its Evolution, Theory and Administration (London: Routledge, 2010), p. 262.

3 Halvard Leira, 'Beskyttelsesplikt over alle grenser?' [Duty of Care Across All Borders?], Norsk Statsvitenskapelig Tidsskrift, vol. 33, no. 1 (2017), p. 79.

4 United Nations, Vienna Convention on Consular Relations (1963), art. 5. 
This makes the 'caretaker' role different from that of 'rescuer', which is the role that often seems to be assigned to states by citizens themselves and by mass media covering individual cases. When faced with emergency situations in the host state such as natural disasters or terrorist attacks, a discrepancy might arise between citizens' expectations and the state's ability or readiness to take action. ${ }^{5}$ Implicit in the 'rescuer' role lies the popular expectation that if push comes to shove, citizen protection will take priority over 'diplomatic protocol'. Especially in cases with a high media profile, states may therefore find themselves facing cross-pressure between on the one hand 'walking the extra mile' for a citizen in need of help, and on the other observing diplomatic conventions. States that keep strictly to a 'caretaker' role may be accused of being politically weak or lacking compassion; and states that adopt a 'rescuer' role may be accused of sidestepping international law. The second presumption underpinning this article arises from this dilemma: that states are more likely to assume the 'rescuer' role when they consider core values underpinning their self-identity to be at stake. This argument is rooted in scholarly contributions holding that states care about their social identities and become attached to them, to the extent that they may even be willing to put their physical security and material interests at risk. ${ }^{6}$

This article explores this dynamic empirically through an in-depth study of one state's evolving response to an international parental child abduction case. Parental child abduction is a field where 'duty of care dilemmas' seem particularly prone to arise: states want to abide by international law, but they also want to protect their children. A single case format allows us to explore in greater detail how tensions between these two concerns may play out in practice. While all parental child abduction cases are of course unique, the broader dilemmas that states face tend to be recurring. The case discussed here is arguably particularly suited for exploration, as it involved one state performing its duty of care in a way that was publicly condemned by another state. In addition, since many of the actors involved shared their version of the events in public, the textual material available is remarkably rich.

The case in question can be summarized as follows. In 2009, a Norwegian mother re-abducted her two children from Morocco, after they had resided there with their father for more than two years against her will. Prior to the

5 Sir Ivor Roberts (ed.), Satow's Diplomatic Practice (Oxford: Oxford University Press, sixth edition 2009), pp. 278-279.

6 For example, Jennifer Mitzen, 'Ontological Security in World Politics: State Identity and the Security Dilemma', European Journal of International Relations, vol. 12, no. 3 (2006), pp. 341-370. 
re-abduction, the Norwegian foreign minister personally authorized a decision to shield the children - who were dual citizens - at the Norwegian Embassy in Rabat, citing 'legal necessity' and 'Norway's duty to protect two Norwegian minors in fear of their lives.' Embassy personnel later also transported the children out of the Norwegian Embassy, and helped them reunite with their mother. While the Norwegian government and embassy maintained that they had nothing to do with the operation that brought the children out of Morocco, Morocco accused Norway of having disrespected Moroccan sovereignty and violated its diplomatic commitments. ${ }^{8} \mathrm{~A}$ diplomatic conflict between the two states followed, which worsened when Norwegian media in early 2010 revealed that two off-duty Norwegian special soldiers had been part of the exit operation. This article argues that the Norwegian government's handling of the case must be seen in light of Norway's self-identity as a frontrunner for children's rights. Ultimately, helping two children in need 'had' to take priority over concerns about political and diplomatic costs.

\section{The Limits of State Care: What States Can and Cannot Do}

Citizens are individuals who, though their inborn or granted citizenship status, legally belong to a given state. With citizenship comes the 'right to have rights' within a particular political community (as put by Hannah Arendt), and the most fundamental of these rights has been 'the right to life, liberty and security of person'. ${ }^{9}$ As Nina Græger and Halvard Leira observe:

The state's responsibilities vis-à-vis its subordinates as part of the social contract are one of the key issues within political theory, political science and international relations. Some of these responsibilities have been regarded as universal or eternal, such as protection against external harm. ${ }^{10}$

$7 \quad$ Norwegian Ministry of Foreign Affairs, 'Child Custody Case in Morocco', press release no. 57 (28 July 2009), available online at www.regjeringen.no/en/aktuelt/norways-role-in -the-recent-events-in-mor/id572352/.

8 Moroccan Ministry of Foreign Affairs and International Cooperation, Communiqué no. 7 (27 July 2009).

9 United Nations General Assembly, Universal Declaration of Human Rights (10 December 1948), art. 3 .

10 Nina Græger and Halvard Leira, The State's Duty of Care in International Relations, paper presented at the IsA Convention, Atlanta (2016), p. 1. 
By a similar token, Xavier Guillaume and Jef Huysmans describe the task of 'securing citizens demanding security' as 'one of the organizing dynamics of modern states and politics more generally'.11 At the same time, it is important to note that as per international law, the primary responsibility for individuals' safety and well-being lies with the state in which they are physically located rather than with the state in which they hold citizenship. Within their own territory, states are responsible not only for their own citizens, but they also have a broader responsibility to preserve 'the right to life and security' of noncitizen residents. ${ }^{12}$ This extended responsibility must be seen in direct relation to the twin principles of sovereignty and non-intervention: states enjoy full sovereignty over their territory, and 'no State or group of States has the right to intervene or interfere in any form or for any reason whatsoever in the internal and external affairs of other States.13

Only under very specific and clearly defined circumstances are states allowed to extend their powers to foreign territory. We may refer to this as extraterritorial practices, which in Turan Kayaoğlu's terms can be defined as 'a legal regime where a state claims exclusive jurisdiction over its citizens in another state.14 Through international agreements, states have the right to exercise power within delimited geographical areas in other states such as embassies and military bases, over certain activities within the boundaries of other states such as environmental laws, and over certain state employees working within the territorial boundaries of another state - such as diplomats, peacekeepers and military personnel. ${ }^{15}$ No such general extraterritorial agreements are currently in place for ordinary citizens. However, protecting nationals abroad is a chief task of the consular service, and citizens travelling or residing abroad will in many cases have a legitimate expectation that their home state will provide them with assistance if needed. Indeed, and as Maaike Okano-Heijmans

11 Xavier Guillaume and Jef Huysmans, 'Introduction: Citizenship and Security', in X. Guillaume and J. Huysmans (eds), Citizenship and Security: The Constitution of Political Being (London: Routledge, 2013), pp. 1-2.

12 United Nations General Assembly, Declaration on the Human Rights of Individuals Who are not Nationals of the Country in Which They Live (13 December 1985).

13 United Nations General Assembly, Declaration on the Inadmissibility of Intervention and Interference in the Internal Affairs of States (9 December 1981).

14 Turan Kayaoğlu, 'The Extension of Westphalian Sovereignty: State Building and the Abolition of Extraterritoriality', International Studies Quarterly, vol. 51, no. 3 (2007), p. 65.

15 Kayaoğlu, 'The Extension of Westphalian Sovereignty', p. 65. The Vienna Convention on Diplomatic Relations 1961 makes it clear that the premises, archives, documents and correspondence of a diplomatic mission, as well as the diplomatic agent and his private residence 'shall be inviolable'. 
observes, in many situations citizens have to rely on their home state when they are in need of assistance abroad, since only states have the legal capacity to perform tasks such as issuing travel documents or negotiating with other governments. ${ }^{16}$ Fulfilling their broader duty to protect their nationals, diplomatic and consular personnel operate within 'a generally accepted international framework supplemented by treaty provisions'. In addition, they are usually guided by more specific instructions that are 'supplied and updated by their sending States as to what they should or may do and on the appropriate procedures. ${ }^{17}$ However, and as many of the case studies discussed in this special issue of The Hague Journal of Diplomacy illustrate, when it comes to the nature of assistance provided, there is 'a large margin of discretion'.18 Moreover, nationals abroad can expect to receive assistance from their home state only as long as this is not seen to be interfering with the receiving state's territorial integrity. Still, states are increasingly asked to assist their citizens abroad also in situations where their room for manoeuvre is limited by diplomatic conventions. ${ }^{19}$ If states provide assistance to their citizens on foreign territory beyond what international agreements prescribe, they run the risk of entering a diplomatic grey zone where the commitment to respect local jurisdiction is put at risk. ${ }^{20}$ From a logic of consequences' point of view, sidestepping international conventions to help a distressed citizen abroad may not always be the most rational choice for a state. First, because non-compliance with diplomatic 'rules, routines and standard operating procedures' could be costly, especially if relations with the other state is deemed politically and economically important. ${ }^{21}$ Second, non-compliance could harm the acting state's reputation

16 Okano-Heijmans, 'Consular Assistance and Consular Diplomacy', p. 31.

17 Okano-Heijmans, 'Consular Assistance and Consular Diplomacy', p. 31.

18 Roberts (ed.), Satow's Diplomatic Practice, pp. 277-278.

19 Roberts (ed.), Satow's Diplomatic Practice, pp. 277-278.

20 At the international level, a related debate has been whether there are situations where concerns about human security should trump concerns about territorial integrity. The doctrine of Responsibility to Protect $(\mathrm{R} 2 \mathrm{P})$ holds that states have the primary responsibility to protect their populations from harm. If states fail to take this responsibility, then the international community has an obligation to respond through 'appropriate diplomatic, humanitarian and other means'. See United Nations General Assembly, 'Resolution Adopted by the General Assembly', A/Res/6o/1 (2005), para. 138-140.

21 For a useful discussion of different 'logics of action', see Ole Jacob Sending, 'Constitution, Choice and Change: Problems with the "Logic of Appropriateness" and its Use in Constructivist Theory', European Journal of International Relations, vol. 8, no. 3 (2002), pp. $443-470$. 
on the international arena, by stigmatizing it as a 'rule-breaker.'. ${ }^{22}$ And third, from a domestic viewpoint, providing care to a citizen abroad beyond what diplomatic instructions prescribe could establish a problematic precedence for a state's future practice of the duty of care: it could raise expectations from other citizens that they will receive the same amount of help in a similar situation. ${ }^{23}$

So why do states in some cases still take extra steps to assist a distressed citizen on foreign territory, despite the political, diplomatic, economic and administrative costs that such assistance may have? The argument proposed here is that concerns about ontological security can explain why states sometimes make an extra effort to help distressed citizens abroad, despite the aforementioned political and economic costs. This argument is rooted in scholarly contributions that states care about their social identities, and - as noted above - become attached to them to the extent that they may even be willing to put their physical security and material interests at risk to protect these identities. ${ }^{24} \mathrm{~A}$ 'favorable image and reputation' seem to matter more and more in international affairs, as is evident for instance in the increased awareness of and investment in public diplomacy and nation-branding programmes. ${ }^{25}$ By contrast, states whose actions are criticized or condemned by other states risk public shaming and loss of status, and must find ways to respond to and manage the stigma that is being imposed on them. ${ }^{26}$ Against this backdrop, we must assume that most states would like to be perceived both as 'good' carers for their citizens and as 'good' international rule-followers. Moreover, based on the theory reflections above, we may expect a state that is faced with a duty-of-care dilemma between whether to put citizen protection first, or diplomatic rule-following, will choose the response that it considers least harmful for its self-identity. ${ }^{27}$ This is likely to be particularly true in cases with a high media profile, and where the media see it as their role to confront states with discrepancies between their self-representations and practical policies. If we apply this insight to the case under scrutiny in this article, then we must further expect that it matters to Norway's practice of the duty of care that Norway

22 Rebecca Adler-Nissen, 'Stigma Management in International Relations: Transgressive Identities, Norms, and Order in International Society', International Organization, vol. 68, no. 1 (2014), pp. 143-176.

23 Leira, 'Beskyttelsesplikt over alle grenser?' [Duty of Care Across All Borders?].

24 Mitzen, 'Ontological Security in World Politics'.

25 Eytan Gilboa, 'Searching for a Theory of Public Diplomacy', Annals of the American Academy of Political and Social Science, vol. 616 (2008), p. 56.

26 Adler-Nissen, 'Stigma Management in International Relations'.

27 Mitzen, 'Ontological Security in World Politics'. 
routinely portrays itself on the international scene both as an international rule-follower and an advocate for children's rights. ${ }^{28}$ In official documents, the Norwegian government stresses its general commitment both to the 'international legal order and multilateral governance systems' and to strengthening 'the rights and needs of women and children' worldwide. ${ }^{29}$ Norway also reports to be striving hard to continue to be 'a frontrunner when it comes to promoting children's rights and abiding by the UN Convention on the Rights of the Child' ${ }^{30}$ This is relevant if we accept the premise that states' actions on the international arena must be understood in light of how they see themselves, and how they would like to be seen by others. When certain (self-)representations acquire dominance in the public discourse over time, they shape states' room for manoeuvre, making some policy options appear more possible, natural and legitimate than others. ${ }^{31}$

\section{Diplomacy and Parental Child Abduction}

The term 'international parental child abduction' is used here with reference to cases where a child is wrongfully removed to or retained in a foreign country by one of its parents, and without the consent of the other parent or the individual/institution exercising custody rights for it at the time. ${ }^{32}$ In recent years, the number of new registered cases per year has been on the increase in many states, not least because of a general rise in international marriages and relationships. ${ }^{33}$ From the outset, states have a very limited toolbox at

28 For scholarly discussions, see for instance Halvard Leira (ed.), Norske selvbilder og norsk utenrikspolitikk [Norwegian Self-Images and Norwegian Foreign Policy] (Oslo: NUPI, 2007), p. 9; see also Cecilie Neumann, 'Barnet som forsvant' [The Child who Disappeared], Internasjonal Politikk, vol. 72, no. 4 (2014), pp. 511-523.

29 See, for example, Norwegian Ministry of Foreign Affairs, 'Setting the Course for Norwegian Foreign and Security Policy', Meld. St. 36/White Paper to the Storting (2016-2017).

30 See, for instance, Norwegian Ministry of Children and Equality, Ny rapport til FN om barnekonvensjonen [New Report to the UN about the Child Convention] (6 October 2016).

31 Iver Neumann, 'Discourse Analysis', in Audie Klotz and Deepa Prakash (eds), Qualitative Methods in International Relations: A Pluralist Guide (London: Palgrave Macmillan, 2008), pp. 61-77.

32 The definition builds on the introductory passages from the Hague Convention on the Civil Aspects of International Child Abduction (1980). For the sake of simplicity, the following will refer to both parties as 'parents'.

33 For instance, in 2012-2013, the British Foreign \& Commonwealth Office (FCO) reported that the number of new registered parental child abduction and international custody 
their disposal when it comes to handling such cases. On the international level, the principal legal document is the Hague Convention on the Civil Aspects of International Child Abduction (hereafter, Hague Abduction Convention) of $1980,{ }^{34}$ whose stated, overall purpose is:

[...] to protect children internationally from the harmful effects of their wrongful removal or retention and to establish procedures to ensure their prompt return to the State of their habitual residence, as well as to secure protection for rights of access. ${ }^{35}$

The phrases 'wrongful removal' and 'state of habitual residence' are of key importance here. Following the principles set out in the Convention, the conditions for 'wrongful removal' have only been met when the child was habitually residing in a signatory state immediately before the removal or retention; when the removal or retention was in breach of custody rights attributed to a person or institution; and when those custody rights were actually being exercised at the time in question. Furthermore, the Convention applies only to children under sixteen years old. If all these criteria are met, and if both states in question are signatories, then it is concluded that the child should be returned to its state of habitual residence as soon as practically possible. ${ }^{36}$ The Convention, then, places emphasis on where the child has habitually been living, rather than on where it was born or holds citizenship. In this respect, the Convention

cases had more than doubled in one decade, from 272 to 580 new cases. See Foreign \& Commonwealth Office, 'New FCO Figures Show Parental Child Abduction Cases on the Rise', press release (12 December 2013), available online at https://www.gov.uk/government /news/new-fco-figures-show-parental-child-abduction-cases-on-the-rise. In Norway, the numbers are more unstable: between 2005-2016, the number of cases varied between 19 (in 2008) and 50 cases (in 2013). See Norwegian government, 'Totalt antall barnebortføringssaker, 2005-2016' [Total Number of Child Abduction Cases, 2005-2016] (27 January 2017). The Convention is currently signed by 94 states. Other important legal documents include EU Regulation 2201/2003, which is designed to enhance the 'return mechanism' introduced in the Hague Abduction Convention within the European area. The Hague Convention on Parental Responsibility and Protection of Children (1996) is broader in scope than the first convention, but re-emphasizes that the child's state of habitual residence should have jurisdiction over the child. In cases of parental child abduction, the 1996 Convention notes that 'the authorities of the Contracting State in which the child was habitually resident immediately before the removal or retention keep their jurisdiction until the child has acquired a habitual residence in another State'.

Hague Convention on the Civil Aspects of International Child Abduction (1980), introductory paragraph.

$36 \quad$ Hague Convention on the Civil Aspects of International Child Abduction, art. 3-4. 
could be seen as preserving 'the status quo' — it is designed as a mechanism for returning children to their state of habitual residence, so that this state 'can determine custody arrangements'. ${ }^{37}$

Of course, even in abduction cases where both of the involved states are signatories to the Hague Abduction Convention, cases may not be resolved. In some instances, signatory states do not comply with the Convention; ${ }^{38}$ in others, it may be difficult to determine whether the criteria for a 'wrongful removal' have been met; or where the child habitually resided. Furthermore, the issue of custody may be unresolved, and the initial removal of the child from its state of residence may have been permitted by the other parent. ${ }^{39}$ In other words, even in cases where the Hague Abduction Convention applies, there are many potential pitfalls, and the child's return is far from guaranteed. Yet, as noted above, the Convention currently represents the most developed international legal platform on which states can collaborate to resolve child abduction cases. In cases where it does not apply, the legal options are even more limited, ${ }^{40}$ and states have a reduced room for manoeuvre when parents left behind turn to them for help.

37 Michelle Boykin, 'A Comparison of Japanese and Moroccan Approaches in Adopting the Hague Convention on the Civil Aspects of International Child Abduction', Family Law Quarterly, vol. 46, no. 3 (2012), pp. 453-454.

38 For instance, in its 2017 Annual Report on International Child Abduction, the us State Department identified thirteen signatory states that have 'demonstrated a pattern of noncompliance' with the Hague Abduction Convention. See us Department of State, Annual Report on International Child Abduction (Washington, DC: Us Department of State, 2017).

The Hague Abduction Convention also makes it clear that if the parent left behind did not exercise parental responsibility at the time of the removal or retention, or had consented to the child travelling out of the country either before or after the alleged abduction took place, then repatriation to the state of habitual residence is not mandatory. The same goes for cases where one year or more has passed since the removal or retention and the child has settled in a new environment; cases where there is 'a grave risk' that repatriation could 'expose the child to physical or psychological harm or otherwise place the child in an intolerable situation'; and cases where the child 'objects to being returned and has attained an age and degree of maturity at which it is appropriate to take account of its views'. See Hague Convention on the Civil Aspects of International Child Abduction, art. 13.

40 Using the United States as her country of reference, Ericka Schnitzer-Reese identified three legal options: turning to local jurisdiction in the home state; finding an agreement through bilateral diplomacy; or invoking the Un Convention on the Rights of the Child (1984). See Ericka Schnitzer-Reese, 'International Child Abduction to non-Hague Convention Countries: The Need for an International Family Court', Northwestern Journal of International Human Rights, vol. 2, no. 1 (2004). 


\section{Working in the Diplomatic Grey Zone}

In Norway, the state whose duty-of-care practices are analysed here, international parental child abduction is a criminal offence. Norwegian authorities' handling of individual cases depends on whether the child has been brought to a signatory or non-signatory state of the Hague Abduction Convention. As a general rule, the ministry of justice will assist parents left behind if the child has been taken to a signatory state; and the ministry of foreign affairs (MFA) if the child has been taken to a non-signatory state..$^{41}$ On its website's information page about international parental child abduction, the Norwegian government makes it clear that in either case, there are essentially two ways in which a solution can be found, both of which leave the parents in charge. The first is to seek an agreement with the other parent for the return of the child to its state of habitual residence; the second is to seek a legal solution in the state to which the child has been taken. ${ }^{42}$ The default position is thus that Norwegian authorities have limited political and diplomatic room for manoeuvre in parental child abduction cases when the child has been taken to a state that is not a party to the Hague Abduction Convention. Norway's self-representation is that of a 'caretaker': the MFA will provide practical assistance and support to parents left behind as they seek their children's return, but will be careful not to be seen as disrespecting local jurisdictions in the country to which the child has been taken. ${ }^{43}$ Norway's MFA makes it clear that it is not in a position to interfere with local jurisdiction, assist citizens in civilian matters, take over the custody of children, or escort children back to Norway. ${ }^{44}$ By a similar token, citizens are advised that Norwegian diplomatic personnel will provide 'whatever assistance they can' to parents left behind, but this assistance is concretized in practical tasks such as establishing contact with local attorneys and offering advice on local conditions, or help concerning travelling, accommodation, contact points, or translation services. It is stressed that while embassy

41 Norwegian government, 'What Is an International Parental Child Abduction?', information page (23 August 2013), available online at https://www.regjeringen.no/en/sub/child -abduction/about-international-child-abduction/what-is-international-child-abduction/ id $732971 /$.

42 Norwegian government, 'What Is an International Parental Child Abduction?'.

43 Norwegian government, 'Child Abduction to/from a Non-Contracting State', information page (26 August 2013), available online at https://www.regjeringen.no/en/sub/child -abduction/about-international-child-abduction/list-of-countries/to-and-from-a -non-signatory-state/id $733003 /$.

44 Norwegian government, 'Hvilken bistand kan UD gi norske borgere i utlandet?' [What Assistance Can the MFA Offer to Norwegian Nationals Abroad?] (30 April 2009). 
personnel in some cases may be present at court hearings or make enquiries about progress in a case, they cannot in any way intervene in legal proceedings in other states. ${ }^{45}$

When it comes to public attention, detailed discussions of parental child abduction cases are rare in Norwegian media, not least because of the Ethical Code of Practice for the Norwegian Press, which calls for caution when it comes to reporting about family matters and cases that involves children. ${ }^{46}$ The case discussed here stands out in this respect, one likely reason being the dramatic way in which it developed, along with the fact that it rose to the state level and triggered a diplomatic conflict. It should also be mentioned that the father in the case was a former Olympic champion and well-known public figure in both Morocco and Norway. This aspect clearly added to public interest in the case. As a result, a large amount of textual material about the case is available in the public sphere. In addition to the extensive media coverage both at the time of the re-abduction and in subsequent years - official press releases and statements about the case were issued both on the Norwegian and the Moroccan sides. Norwegian authorities later also released two reports, following internal inquiries into what part government officials had played in the events, and the case was subject to debate in the Norwegian Parliament. Finally, both parents and children have shared their version of the events in public: the mother published her account in a book co-authored with her lawyer in 2010; the father has given multiple statements to the press; and both children have also been interviewed about the case by Norwegian media. Together, this material presents us with a rare opportunity to trace and analyse how a government and its diplomatic apparatus presented and made sense of their actions during and after the unfolding of a difficult child abduction case, and how those same actions were interpreted and portrayed by other parties as well as external observers. ${ }^{47}$

\footnotetext{
45 Norwegian government, 'Child Abduction to/from a Non-Contracting State'.

46 Norwegian Press Association, 'Code of Ethics of the Norwegian Press' (13 June 2015), available online at http://presse.no/pfu/etiske-regler/vaer-varsom-plakaten/vvpl-engelsk/.

47 In the analysis, the texts are treated as individual accounts of what happened rather than as 'facts' - that is, they are representations competing for authority in the wider public debate. This amounts to a discourse analytical approach, as described in Neumann, 'Discourse Analysis'.
} 


\section{The Default Position: The State as 'Caretaker'}

News about the case first broke in the Norwegian and Moroccan press in the summer of 2009. In what one Norwegian newspaper termed 'a dramatic escape, ${ }^{48}$ a Norwegian mother had transported her two children - aged thirteen and sixteen - out of Morocco on a sailboat, bringing them back to Norway after they had resided more than two years in Morocco with their father. Prior to the re-abduction, the mother had unsuccessfully sought the children's return to Norway through other channels, legal and diplomatic. Finding a solution had been difficult from the outset. Not only did the children have dual citizenship, but they had also been temporarily residing in Morocco when the battle over custody began. Moreover, Morocco had not signed the Hague Abduction Convention at the time ${ }^{49}$ meaning that there was no shared legal framework to which the two states involved could turn. As for Norwegian-Moroccan relations more broadly, they are generally depicted as 'good', although the Norwegian MFA describe trade and economic relations as 'relatively modest'.50

As the Hague Abduction Convention did not apply, the case fell under the responsibilities of the Norwegian MFA rather than the ministry of justice. In the mother's account of the events, the MFA and the Norwegian Embassy in Rabat both appeared in the default role of 'caretaker' when she first contacted them about the case back in 2007. The embassy informed her that getting the children out of Morocco would be difficult, since the father, per Moroccan law, would have to give his consent. By the same token, an MFA representative in Oslo reportedly described her case as a 'mission impossible', noting in particular the challenges related to the fact that the children were also Moroccan citizens. In her book, the mother describes how the MFA offered her guidance about possible paths she could pursue, but the core advice she received was to seek a peaceful solution with the father if possible. Subsequent communication seems to have followed a similar pattern: she was given practical advice and support, but the recurring response was that there was little the Norwegian government could do to help. In her book, the mother expresses frustration with what she portrays as a wary approach from Norwegian

48 'Dramatisk flukt fra Marokko' [Dramatic Escape from Morocco], Dagbladet (28 July 2009).

49 Morocco acceded to the Convention in 2010. However, since the children were residing in Morocco when the custody battle began, the Hague Abduction Convention might not have been applicable in any case.

$50 \quad$ Norwegian Embassy in Morocco, 'Om Marokko' [On Morocco], information page (undated). 
authorities. ${ }^{51}$ Following a meeting with the MFA, together with her attorney, she observed:

Our impression after the meeting, based on their response, was that they were not doing anything at all. It was incomprehensible that Norwegian authorities did not do anything when Norwegian citizens were faced with such serious difficulties as in my case. We both felt that the Ministry was using its energy to inform us that it could not do anything, rather than to look for solutions. We were tired of hearing time and again that this was a family conflict that we had to try and resolve peacefully. ${ }^{52}$

This passage suggests that there was, from the outset, a discrepancy between the forsaken parent's hopes and expectations of what Norwegian authorities could do to help, and what the MFA and embassy deemed possible.

\section{Invoking the Duty of Care: From Caretaker to Rescuer}

In March 2009, the case took an unexpected turn when the two children ran from their father's custody, and called the Norwegian Embassy in Rabat's emergency telephone for help. Embassy personnel agreed to pick the children up by car, but eventually decided to drive them to the local police station rather than to the embassy's premises. According to their mother, when she later spoke with the Norwegian ambassador to Morocco on the telephone, he explained to her that the embassy was obliged to inform Moroccan authorities about the incident, and he also indicated that it might be best if the children returned to their father. This was also the result: the children were returned to their father after a Moroccan judge ruled that they should remain in his care until the case had been processed in the Moroccan court system. Also on this occasion, the mother portrayed the embassy as sticking to the default role as 'caretaker' and 'rule-follower'.53

Then, in July 2009, a dramatic situation again emerged, when the children ran away from their father for the second time. This time as well, they contacted the Norwegian Embassy in Rabat, and once again they were picked up

$51 \quad$ Marte Svarstad Brodtkorb and Anne Cecilie Hopstock, Hvis jeg roper høyt nok: En mors kamp for sine barn [If I Shout Loud Enough: A Mother's Fight for Her Children] (Oslo: Kagge, 2010), pp. 64-73.

$5^{2}$ Brodtkorb and Hopstock, Hvis jeg roper høyt nok [If I Shout Loud Enough], p. 124.

53 Brodtkorb and Hopstock, Hvis jeg roper høyt nok [If I Shout Loud Enough], pp. 165-168. 
by embassy personnel - on this occasion, by the embassy's police attaché. Subsequent articles in Norwegian newspapers describe how the Norwegian government, as well as the MFA and individual embassy personnel, found themselves faced with a dilemma between putting citizen care or diplomatic rule-following first. As the MFA in Oslo embarked on an internal discussion as to whether it would be legal to shield children in the embassy's premises, the police attaché reportedly drove around with them in Rabat. Eventually, the Norwegian foreign minister personally authorized interpretation of the situation as 'a matter of legal necessity'. It was decided that the two children could stay in the ambassador's residence until their mother or someone acting on her behalf could pick them up. ${ }^{54}$ The Norwegian ambassador also permitted one of the embassy's employees to escort the children out of the embassy, and to drive them to a place where a person acting on their mother's behalf would collect them. ${ }^{55}$

By agreeing to shield the children in the embassy's premises, and to escort them out again and help them reunite with their mother, it could be argued that Norwegian authorities disregarded the fact that they were also Moroccan citizens, and thus moved from the default 'caretaker' role into a 'rescuer' role. Such an interpretation finds support in the Norwegian foreign minister' own statement to Norwegian national media, following a telephone conversation with his Moroccan counterpart shortly after the events, in which he stated:

I recognized that [the children] were in danger, and explained to [the Moroccan foreign minister] that this was the reason why they were allowed to stay at the residence. I expressed respect for the fact that they are Moroccan citizens, but asked him to respect the fact that they are also Norwegian citizens, and that a case can have two sides. ${ }^{56}$

The Norwegian foreign minister indicated that he had had little other choice, under the circumstances, than to put the duty to care for the two children first, even if it meant putting diplomatic relations with Morocco at stake. And he presented his Moroccan counterpart with what could be seen as an ultimatum:

\footnotetext{
54 Cited in 'Støre åpnet ambassaden i nødverge' [Støre Opened the Embassy Out of Legal Necessity], VG (29 July 2009).

55 '-Det er vanskelig å tilgi min far' [-It is Difficult to Forgive My Father], Aftenposten (23June 2017).

$5^{6} \quad$ 'Støre åpnet ambassaden i nødverge'.
} 
either to let the children leave Morocco; or to guarantee their safety in Morocco, under the mother's supervision. ${ }^{57}$

Reporting about the story, Norway's largest tabloid newspaper commended the Norwegian foreign minister for his decision to shield the two children at the embassy, concluding in an editorial that 'children who come into situations like this should be able to feel certain that Norwegian authorities are doing what they can to help'. The foreign minister, the newspaper maintained, had done the right thing when he 'let diplomatic etiquette come second. ${ }^{58}$ To the newspaper, then, it seemed self-evident that concern for two children's safety and well-being should come before concerns about diplomatic conventions, or political and economic costs.

\section{The Diplomatic Costs of Caring}

Shortly after the two children had left Morocco, the Moroccan Ministry of Foreign Affairs and Cooperation (MFAC) released a press communiqué. In unusually sharp language, the MFAC accused the Norwegian government of having violated its commitments under the Vienna Convention on Diplomatic Relations (1961) - specifically, for not having respected 'the laws and regulations of the receiving State' in its handling of the case. ${ }^{59}$ The MFAC condemned the Norwegian Embassy in Rabat's 'evident' and 'illicit' involvement in the process leading up to the children's departure, and concluded that the Norwegian embassy had shown contempt for Moroccan law by helping the mother transport two Moroccan children out of the country. ${ }^{60}$ In the communiqué, Morocco portrayed Norway as a 'rule-breaker' - a state that had violated its international commitments and disrespected Moroccan sovereignty.

The Norwegian government, however, maintained that the MFA and Norwegian Embassy in Rabat had played no part in the actual re-abduction of the children: it had not been informed about, far less been involved, either in helping the children run from their father or in transporting them out of Morocco. Confronted by Norwegian media with the Moroccan authorities' strong allegations, the Norwegian MFA replied that it could not see 'that

57 'Støre åpnet ambassaden i nødverge'.

58 'Flukten fra Marocco' [The Escape From Morocco], Editorial, vG (30 July 2009).

59 Moroccan Ministry of Foreign Affairs and International Cooperation, Communiqué no. 7 (27 July 2009).

6o Moroccan Ministry of Foreign Affairs and International Cooperation, Communiqué no. 7 . 
Norwegian authorities in any way have done anything wrong in this case. ${ }^{61}$ In a statement, the Norwegian foreign minister stated that the children had left the embassy of their own accord, after which the Norwegian authorities had no contact with them, and consequently were not in any way involved with their leaving Morocco. ${ }^{62} \mathrm{He}$ also stressed that the children had arrived at the embassy's premises voluntarily, and defended the decision to shield them there, pointing to 'the seriousness of the case', and the fact that the children had been facing 'threats to their lives.' ${ }^{63}$

These two conflicting accounts - of Norway as a 'rule-breaker' and Norway as a 'rescuer, but rule-follower' - marked the beginning of what became a long-standing diplomatic conflict between Norway and Morocco. Shortly after the events, the Norwegian ambassador to Morocco left the country 'for security reasons'. He never returned, reportedly because of the clear signals from the Moroccan government that it would be difficult to restore a good working relationship with him. ${ }^{64}$ More than a year after the original events, a new Norwegian ambassador had yet to be appointed, because, according to Norwegian media, Moroccan authorities were obstructing the process. ${ }^{65}$ In the weeks and months after the re-abduction, the Moroccan government sharpened its criticism of how Norwegian authorities had handled the case. In another press communiqué released in August 2009, the MFAC accused Norwegian embassy personnel of having played a direct role in the operation leading to the children's departure from Morocco, and called for the organizers of the escape to be held accountable and legally prosecuted. ${ }^{66}$

In January 2010, the diplomatic conflict escalated further, following a Norwegian newspaper's disclosure that two off-duty Norwegian special soldiers had played a role in the rescue manoeuvre that brought the children out of Morocco. ${ }^{67}$ This new piece of information received massive media attention

61 'Støre avbrøt ferien for kidnappingssaken' [Støre Interrupted His Vacation for the Abduction Case], Dagbladet (28 July 2009).

62 Norwegian Ministry of Foreign Affairs, 'Child Custody Case in Morocco'.

63 Norwegian Ministry of Foreign Affairs, 'Child Custody Case in Morocco'.

64 'Ambassadøren FERDIG' [The Ambassador DONE], VG (14 January 2010).

65 'Norge mangler ambassadør i Marokko' [Norway without Ambassador to Morocco], NTB (30 July 2010). Morocco accredited a new Norwegian ambassador to Morocco in November 2010.

66 Moroccan Ministry of Foreign Affairs and International Cooperation, Communiqué no 8 (17 August 2009). See also 'Marokko med nye anklager mot Norge' [Morocco with New Accusations Against Norway], VG (18 August 2009).

67 'Norske spesialsoldater smuglet Skah-barna ut av Marokko' [Norwegian Special Soldiers Smuggled the Skah Children Out of Morocco], VG (30 January 2010). 
in Norway. However, the Norwegian government did not change its account of how events had unfolded, nor of the role that the Norwegian government and embassy had played. A spokesperson for the Norwegian MFA informed the press that the ministry would contact Moroccan authorities and reassure them that the individuals in question had acted in a private capacity the Norwegian government had neither known about nor approved of their involvement. ${ }^{68}$ At a press conference, the Norwegian minister of defence called the soldiers' involvement 'unacceptable', and made it clear that their participation had not in any way been authorized by their employer. Similarly, the Norwegian foreign minister, who was also present at the press conference, reaffirmed that the MFA had had nothing to do with the operation that brought the two children out of Morocco. ${ }^{69}$ These assurances were not considered satisfactory for the Moroccan side, however. In a public statement that was widely cited in the Norwegian and international press, the Moroccan foreign minister accused the Norwegian embassy of having imposed 'its own justice on the territory of a sovereign state in a private affair and beyond all rules and ethics.' ${ }^{70}$

These two competing representations of the Norwegian authorities' role in the case lived on. Only a few weeks later, in February 2010, an internal inquiry into the role of the Norwegian MFA in 'the Morocco case' concluded that the MFA had not authorized, planned or organized 'the private operation [the mother] initiated to transport her children out of Morocco and to Norway'. ${ }^{71}$ Commenting on the report, the Norwegian foreign minister said he was satisfied with its conclusion: that Norway had not broken any rules. Yet he also added: 'We prioritize cases that involve children. When Norwegian children's safety is threatened, it is our duty to assist, and this case revealed a very serious situation for the two children. ${ }^{72}$

While the minister maintained that Norwegian authorities had nothing to do with the re-abduction (that is, it was not a 'rule-breaker'), he also indicated that in the prior events, Norway had little other choice than to put its concern

68 'Norsk diplomat involvert i Skah-saken' [Norwegian Diplomat Involved in the Skah Case], NTB (1 February 2010).

69 Cited in 'Marinejegere hentet ungene til Skah i egen ferie' [Off-Duty Marines Collected Skah's Children], NRK (1 February 2010).

$70 \quad$ 'Morocco Says Norway Must Punish Wayward Diplomats', Reuters (3 February 2010). See also 'Morocco Olympic Champion's Children “Not Abducted”', вBс (2 February 2010).

71 Norwegian Ministry of Foreign Affairs, 'Gjennomgangen av utenrikstjenestens rolle i Marokko-saken' [Review of the MFA's Role in the Morocco Case], press release 16/2010 (17 February 2010).

72 Norwegian Ministry of Foreign Affairs, 'Gjennomgangen av utenrikstjenestens rolle i Marokko-saken' [Review of the MFA's Role in the Morocco Case]. 
for the two children first (that is, it was also a 'rescuer'). Around the same time, following an internal inquiry into the role of the special soldiers in the case, it was concluded that no disciplinary action would be taken against them 'technically', what they had done was 'not in breach of military criminal code or existing directives.' ${ }^{73}$ Responding to this latest development, Morocco's ambassador to Norway said that the Norwegian government's handling of the case had put Morocco's 'dignity and sovereignty' at stake. 'What if two officers came to Norway from another country, and acted completely in defiance of Norwegian law?', he asked rhetorically. ${ }^{74}$

In an exchange in the Norwegian Parliament around the same time, a member of parliament from one of the largest opposition parties commended the Norwegian government for its handling of the Morocco case. At the same time, he called for more explicit guidelines concerning how similar child abduction cases should be handled in the future. Juxtaposing the state's roles as 'caretaker' and 'rescuer', he noted that while it was 'good to establish websites, etc., so that people can acquire information', what mattered in the end was what Norwegian authorities would 'actively do in these cases to get the children back [...] to Norway', especially when children had been taken to a state that was not party to the Hague Abduction Convention. ${ }^{75}$ In his response, Norway's minister of justice acknowledged that Norwegian authorities were often faced with 'considerable challenges' in child abduction cases such as the one in Morocco. 'This is to a large extent a matter of implementing decisions on foreign territory, and that is not easy', he said, adding: 'We cannot send Norwegian police officers to bring back children either from Palau or other states where we are faced with child abduction cases. ${ }^{76}$

In an interview about the case in Norway's largest printed newspaper several years after the events discussed in this article took place, the former Norwegian Ambassador to Morocco maintained that the embassy had known nothing about the plans to re-abduct the children, although they of course had 'understood that something was going on'. ${ }^{77}$ Still defending the embassy's overall handling of the affair, he argued that there had been 'no other way

\footnotetext{
73 'Skah-saken: Marokkos ambassadør reagerer' [The Skah Case: Reaction from Morocco's Ambassador], VG (15 February 2011).

74 'Skah-saken' [The Skah Case].

75 Hans Frode Kielland Asmyhr, Oral Question Time, Official Report of the Proceedings of the Storting (3 February 2010).

76 Knut Storberget, Oral Question Time, Official Report of the Proceedings of the Storting (3 February 2010).

77 Cited in '-Det er vanskelig å tilgi min far'.
} 
to do it' given the children's situation, and that the response in any case was in line with diplomatic conventions. 'Frankly, it was most tempting to break Moroccan law, put them in the car and drive them far away. But we didn't', he said. ${ }^{78}$ Statements such as these indicate that it remains important for Norwegian officials not only to reject the claims of Norwegian rule-breaking behaviour in the case in question, but also to stand by the decision to help the two children, given Norway's duty to protect its children from harm.

\section{Conclusion}

At what point and in what situations might states be willing to put care of their citizens before diplomatic conventions? Looking specifically at the complex field of international parental child abduction, this article has explored how one modern welfare state practised the duty of care in a child abduction case where there were few agreements or mechanisms in place for resolving the case. Initially, the Norwegian MFA and Norwegian Embassy in Rabat assumed a default role as 'caretaker', recurrently stressing that they could not undertake any action that could be seen as interfering with Moroccan sovereignty and jurisdiction. However, when the children ran from their father and turned to the Norwegian embassy for help, the Norwegian government found itself faced with a tough dilemma. The first time it happened, embassy personnel drove the children to the local police, after which they were returned to their father. The second time the children ran away, the Norwegian foreign minister personally granted them political asylum at the embassy's premises. Embassy personnel also transported the children out of the embassy, and handed them over to a person acting on the mother's behalf.

For a long period after these events, diplomatic relations were strained between Norway and Morocco. The Norwegian government maintained that it had nothing to do with the concrete operation that took the children out of Morocco, at the same time as it defended its involvement prior to this point, citing Norway's duty of care for two minor citizens in fear of their lives. The Moroccan government made it clear that it did not believe Norwegian officials' version of the events, and accused the Norwegian government of having acted in breach of international conventions. Thus, two representations of Norway's practice of the duty of care stood against one another: of Norway as a 'rescuer but rule-follower'; and of Norway as a 'rule-breaker'.

78 '-Det er vanskelig å tilgi min far'. 
This article has suggested that the Norwegian government's response to this case must be understood in light of Norway's strong self-identity as an international frontrunner for children's rights. Defending their actions in the run-up to the re-abduction, the Norwegian foreign minister presented it as impossible for Norway not to help two Norwegian children in need of help. The emergency situation pushed Norway into a 'rescuer' role, where concern for the two children ultimately trumped concerns about political and diplomatic costs.

What can this case tell us about the ways in which modern welfare states practise their duty of care in child abduction cases more broadly, and the circumstances under which they are more likely to step from a caretaker role and into a rescuer role? The case discussed here is unique when it comes to the states and individuals involved and the specific unfolding of events. It also stands out from most parental child abduction cases, in that it involved extensive media coverage. Still, the broader dilemmas that the case exemplifies should be relevant also to other cases where a state's concern for a child citizen's safety and well-being conflict with its obligation to follow diplomatic conventions.

Kristin Haugevik is a Senior Research Fellow at NUPI, the Norwegian Institute of International Affairs in Oslo. She holds an MA and Ph.D. in Political Science from the University of Oslo. Haugevik's research at NUPI focuses on IR theory, inter-state cooperation and 'special relationships', diplomacy, European and transatlantic security politics, and Norwegian and British foreign policy. 